\title{
RESIKO PENULARAN INFEKSI DI RUANG AUTOPSI DAN PENERAPAN KEWASPADAAN UNIVERSAL
}

\author{
Citra Manela
}

\begin{abstract}
Abstrak
Peningkatan resiko penularan infeksi di ruang autopsi semakin meningkat. Hal ini terjadi karena peningkatan jumlah kasus korban meninggal yang terinfeksi penyakit terutama di negara berkembang. Beberapa studi menyatakan terjadinya peningkatan prevalensi HIV, hepatitis $B, C$, D dan G, tuberkulosis, penyakit Prion, Hantavirus, campak, infeksi bakteri atau HTCV pada pekerja di ruang autopsi. Penerapan kewaspadaan universal, termasuk standar OSHA, pemilihan disinfektan dan pengolahan limbah medis sangat penting diperhatikan untuk mencegah resiko terjadinya penularan infeksi. Tujuan penulisan tinjauan pustaka ini adalah mengetahui risiko penularan infeksi pada pekerja di ruang autopsi dan penerapan kewaspadaan universal. Penulisan ini berdasarkan studi kepustakaan yang terkait dengan dua topik ini. Penerapan kewaspadaan universal sangat diperlukan dalam pencegahan penularan penyakit infeksi pada pekerja di ruang autopsi yaitu meliputi penggunaan alat pelindung diri yang tepat, perilaku, tindakan mencegah infeksi, disinfeksi dan penanganan sampah medis yang sesuai aturan.
\end{abstract}

Kata kunci : penularan infeksi, kewaspadaan universal, disinfeksi

\begin{abstract}
The risk of infection transmissions in autopsy room is increasing. This happens because the increase of the number of cases died affected by infectious disease, especially in developing countries. Several studies found an increase on the prevalence of HIV, Hepatitis $B, C, D$ and $G$, Tuberculosis, Prion Disease, Hantavirus, Measles, Bacterial Infection or HTCV on workers in autopsy room. The application of universal precaution, including OSHA standards, the selection of disinfectant, medical waste management is very important to prevent the risk of the infection transmission. The aim of this review was to explain the risks of infection transmissions on workers in autopsy room and the application of universal precaution. Literatures on these two topics were evaluated. Application of universal precautions are very necessary in the prevention of transmission of infectious disease in workers in the autopsy room which includes the use of appropriate personal protective equipment, behaviors, actions to prevent infection, disinfection and treatment of medical waste according to the rules.
\end{abstract}

Keywords: transmission of infection, universal precaution, disinfection

Afiliasi Penulis : Citra Manela, Bagian Forensik dan Medikolegal Fakultas Kedokteran Universitas Andalas, Padang. Korespondensi: Citra Manela, Bagian Forensik dan Medikolegal Fakultas Kedokteran Universitas Andalas, Jl. Peritnis Kemerdekaan No. 94, PO BOX 49 Padang 25127, Email: manela_84@yahoo.com, Telp: +6281382363552. 


\section{PENDAHULUAN}

Praktek kedokteran forensik berhubungan dengan peningkatan resiko penularan infeksi yang signifikan di banding praktek spesialis kedokteran lain, baik penularan penyakit lewat udara maupun penularan penyakit melalui parenteral. ${ }^{1} \mathrm{Hal}$ ini dikarenakan kasus meninggal karena penyakit infeksi saat ini semakin meningkat terutama di negara berkembang. ${ }^{2}$ Beberapa studi menyatakan terjadinya peningkatan prevalensi HIV, Hepatitis B, C, D, dan G, Tuberkulosis, Penyakit Prion, Hantavirus, Campak, Infeksi bakteri atau HTCV pada pekerja di ruang autopsi. ${ }^{1}$

Penyakit menular masih menjadi salah satu masalah kesehatan dunia. Lebih dari 2 miliar penduduk dunia terinfeksi virus Hepatitis $B$ dn lebih dari 350 juta jiwa diantaranya mengidap hepatitis kronis. Sementara itu penderita hepatitis $\mathrm{C}$ di seluruh dunia mencapai 130 juta hingga 170 juta jiwa dengan angka kematian 350 ribu orang per tahun. Indonesia merupakan salah satu negara berkembang yang masih memiliki masalah penyakit menular. Pada tahun 2011 tercatat beberapa wabah penyakit seperti hepatitis, flu burung dan SARS. Saat ini jumlah penderita hepatitis masih sangat tinggi terutama hepatitis $B$ dan C. $^{2}$

Jumlah penderita hepatitis B dan C di Indonesia mencapai 30 juta jiwa. Hepatitis merupakan penyakit yang banyak merenggut nyawa penduduk Indonesia di usia produktif. Di pedesaan hepatitis menjadi penyebab kematian nomor satu bagi penduduk usia 15-44 tahun, sedangkan diperkotaan menjadi penyebab kematian ketiga. Demikian pula angka kejadian flu burung di Indonesia. Menurut WHO (sejak tahun
2003-2008) jumlah kasus flu burung pada manusia di Indonesia sebanyak 133 kasus dan 108 diantaranya meninggal. $^{2}$

Salah satu penyakit menular lainnya yang saat ini menjadi perhatian di Indonesia adalah HIV-AIDS, karena angka kejadian yang meningkat dengan sangat cepat. Virus HIV masih tetap aktif selama kurang lebih empat jam didalam tubuh penderita yang telah meninggal sehingga tetap berpotensi menular pada orang disekelilingnya. Penularan dapat terjadi melalui cairan-cairan yang keluar dari dalam tubuh jenazah. ${ }^{2}$ HIV masih ditemukan pada $5 \%$ sampel darah yang diambil dari pasien AIDS setelah 24 jam postmortem. Kemudian masih ditemukan pula adanya infeksi retrovirus didalam jaringan, tulang dan darah setelah enam hari postmortem dan dari limpa setelah dua minggu postmortem. Sedangkan pada penelitian lain dikatakan bahwa HIV ditemukan didarah setelah 16,5 hari postmortem pada jenazah di dalam lemari pendingin. ${ }^{3}$ Sehubungan dengan hal tersebut kepada orang-orang yang merawat jenazah dengan HIV-AIDS harus tetap waspada guna menghindari penularan. $^{2}$

Autopsy safety belum menjadi pertimbangan hingga tahun 1980-an ketika kasus infeksi HIV pertama kali muncul. Pada awalnya hal tersebut masih baru ditekankan pada pencegahan infeksi dengan menegakkan kewaspadaan universal dan pengembangan peraturan Occupational Safety and Health Adminsitration (OSHA). Sejalan dengan itu diberlakukan peraturan-peraturan dan prosedur untuk meminimalisir kemungkinan terjadinya luka dan tertusuk jarum. Bahaya-bahaya lainnya teridentifikasi seiring berjalannya waktu 
dan penanganan yang sesuai diberlakukan dalam tingkatan yang bervariasi. ${ }^{4,5}$

Walaupun peraturan OSHA awalnya ditentang dan disambut dengan keengganan, peraturan-peraturan tersebut pada akhirnya memiliki dampak yaitu menciptakan kesadaran akan pentingnya autopsy safety. Hal ini sangat penting karena sebagian besar kecelakaan kerja adalah disebabkan faktor kelalaian manusia dan kesadaran akan perlindungan diri. Dalam autopsy safety semua telah diatur sedemikian rupa agar mencegah terjadinya penularan infeksi, mulai dari syarat-syarat kamar autopsi, alat pelindung diri yang digunakan dalam pemeriksaan dan langkah-langkah disinfeksi kamar autopsi. ${ }^{4,5}$ Tujuan penulisan tinjauan pustaka ini adalah mengetahui risiko penularan infeksi pada pekerja di ruang autopsi dan penerapan kewaspadaan universal.

\section{METODE}

Penulisan tinjauan pustaka ini berdasarkan studi kepustakaan yang terkait dengan risiko penularan infeksi pada pekerja di ruang autopsi dan penerapan kewaspadaan universal.

\section{HASIL DAN PEMBAHASAN}

\section{Resiko Penularan Infeksi di Ruang Autopsi}

Setelah proses kematian, maka terjadilah perubahan pada tubuh jenazah. Invasi endogen oleh bakteri ke cairan serebrospinal dan usus terjadi 4 6 jam setelah kematian. Agen mikroba ini dapat berpindah ke seluruh tubuh 4-8 jam setelah kematian. Multiplikasi mikro- ba mulai terjadi 4 jam setelah mati somatik dan mencapai puncak 3-3,5 x 106 organisme per milliliter cairan tubuh atau per gram jaringan tubuh selama 2430 jam. Penularan organisme dari jenazah ke petugas di ruang autopsi bisa melalui tubuh jenazah yang terbuka dan kontaminasi dari permukaan yang berdekatan. Perpindahan organisme juga bisa melalui udara berupa droplet atau partikel kering yang dapat meningkatkan resiko infeksi. $^{6}$

Penelitian yang dilakukan oleh Sorin Hostiuc et al menggunakan sampel udara di ruang autopsi, menggunakan cawan petri yang berisi agar, agar darah, chapman, empedu-esculin-agar dan media Mac Conkey didapatkan jenis bakteri E.coli, Ps.aeruginosa, St.faecium, Yersinia enterocolitica, enterobacter aerogenes, S.cholerasuis, St.aureus, St.epidermidis, S. coli, Nisseria (m.g), dan Str. Pneumonie. Sedangkan swab kapas yang diambil dari pintu utama ruang autopsi, tiga meja autopsi dan dua jendela didapatkan bakteri kokus gram positif terkadang dalam bentuk diplo atau rantai kecil. Uji imunologi didapatkan virus hepatitis B dan HIV pada waktu hampir 24 jam setelah autopsi. ${ }^{1}$

Penelitian ini didapatkan bahwa dengan metode dekontaminasi standar masih memiliki keterbatasan dalam menghilangkan jejak virus yang akan mengarahkan kepada penularan resiko infeksi. ${ }^{1}$ Penelitian yang dilakukan oleh Hostiuc et al mendapatkan bahwa kemungkinan resiko infeksi Staphylococcus secara transkutan pada seseorang yang memiliki luka terbuka ketika memasuki ruang autopsi. Streptococcus group D ditemukan pada saluran cerna dan saluran kemih. Oleh karena itu dapat terjadi resiko tinggi 
kontaminasi infeksi tersebut saat melakukan pembukaan saluran cerna dan saluran kemih. Walaupun Streptococcus group D berkaitan dengan berbagai macam penyakit infeksi pada manusia, keberadaan bakteri tersebut di uadara tidak berbahaya. Beberapa penelitian tidak dapat menentukan hubungan antara air-borne enterococci dan penyakit infeksi pada manusia. Walaupun demikian tindakan pencegahan harus didapatkan pada orang-orang dengan tingkat imun yang rendah. ${ }^{1}$

Prevalensi tuberkulosis di Romania pada populasi umum adalah 25/100.000 penduduk. Berdasarkan sebuah penelitian yang dilakukan selama 32 tahun tentang prevalensi tuberkulosis pada petugas kesehatan seperti dokter/perawat ditemukan 60 kasus tuberkulosis diderita oleh perawat pada 220 tenaga kesehatan yang diperiksa, 6 kasus pada dokter, dimana rata-rata pertahun adalah 1363/100.000 yaitu sepuluh kali lipat lebih tinggi dibanding populasi umum. ${ }^{7}$

Petugas autopsi memiliki sepuluh kali lipat resiko dan resiko relatif terkena infeksi tuberkulosis yaitu 100-200 kali lebih tinggi dibanding populasi umum. ${ }^{8}$ Berdasarkan hal tersebut dapat diambil kesimpulan bahwa minimal satu dari lima petugas autopsi akan terinfeksi tuberkulosis sepanjang hidupnya. ${ }^{9}$ Resiko berkembangnya infeksi tuberkulosis pada petugas forensik Romania sangat dipengaruhi oleh banyaknya tindakan autopsi pada mayat dengan lesi makroskopis dan alat pelindung diri pada saat autopsi yang kurang memadai seperti tidak menggunakan masker sebagai alat pelindung diri minimal. Dari 15.935 tindakan autopsi yang dilakukan di National Institute of Legal Medicine dari tahun 2002 hingga 2009 didapatkan 316 kasus diantaranya positif terinfeksi oleh tuberkulosis (1,95\%). Jika angka ini diambil kemudian dikalikan 10 ( jumlah petugas minimal yang hadir di ruang autopsi pada saat dilakukan autopsi) didapatkan total lebih dari 3000 yang potensial berkontak dengan infeksi. Hal ini menunjukkan pentingnya masalah penyebaran infeksi tuberkulosis di ruang autopsi. $^{1}$

Hepatitis B mempunyai angka transmisi paling tinggi diantara virus parenteral dengan rata-rata sekitar 100 kali lebih besar dari pada HIV. Hepatitis $B$ dapat menjadi infeksi laten dengan peningkatan resiko penyakit kronik dan karsinoma hepatobilier atau infeksi akut dengan angka kesembuhan yang tinggi. Resiko kontaminasi sangat tinggi untuk petugas kesehatan dari pada populasi umum. Resiko paling tinggi terdapat pada orang yang berkontak dengan darah atau orang yang melakukan tindakan invasif. Contohnya dokter di India yang telah bekerja lebih 3221dari 20 tahun memiliki prevalensi $30 \%$ sedangkan prevalensi populasi umum hanya 5\%. CDC menemukan resiko infeksi umum per orangan pada autopsi sekitar 5\% sedangkan jika darahnya terkontaminasi dengan antigen $\mathrm{HbeAg}$ terjadi peningkatan menjadi $30 \%{ }^{9} \quad \mathrm{Di}$ Austria resiko tertinggi teridentifikasi pada perawat $(30,6 \%)$, petugas pembantu dokter $(30,4 \%)$, dokter $(13,9 \%)$, petugas labor (2,9\%) dan lainnya $(22,3 \%)^{10}$

Penelitian yang dilakukan di US menemukan resiko paling tinggi untuk infeksi HBV adalah diantaranya dokter bedah dan dokter forensik ( sekitar $6 \%$ ). HBV terdapat dalam semua cairan tubuh termasuk saliva, darah, cairan semen 
dan cerebrospinal. Infeksi biasanya terjadi secara parenteral (lewat jarum suntik) tetapi dapat juga terjadi lewat paparan jaringan mukosa dengan cairan terinfeksi (partikel dari cairan tindakan selama pembukaan rongga kepala yang dapat dengan mudah mencapai konjunctiva atau rongga mulut). Tidak seperti HIV, HBV dapat hidup diluar tubuh selama 7 hari pada darah kering atau pada cairan tubuh yang telah mengering. ${ }^{11}$

Infeksi HIV jarang sekali dikutip, contohnya pada tahun 1992 seorang ahli forensik terluka saat melakukan autopsi pada pasien yang mengalami gangguan neurologi progresif. Luka tersebut sekitar $1 \mathrm{~cm}$ dan terjadi saat pembukaan kulit kepala. Pemeriksaan ELISA ditemukan HIV dengan hasil negatif, walaupun demikian pemeriksaan follow up yang dilakukan setelah enam minggu menunjukkan hasil positif. ${ }^{1}$

Kasus infeksi HIV pada tenaga kesehatan di USA selama 11 tahun (1991-2001) sebanyak 23951 kasus, walaupun sebesar $91 \%$ kasus tidak berhubungan dengan paparan saat bekerja, sedangkan 9\% yang positif dapat disimpulkan secara pasti hubungannya dengan aktifitas medis. Sekitar 200 kasus yang berkorelasi positif paling banyak didapatkan dari paparan perkutaneus dan 8 kasus disebabkan oleh paparan kutaneomukosal. $^{12}$

\section{Tabel 1. Resiko Infeksi dan Organisme Penyebab ${ }^{6}$}

\begin{tabular}{ll}
\hline \multicolumn{1}{c}{ Resiko infeksi } & \multicolumn{1}{c}{ Organisme } \\
\hline Virus yang Penularan Melalui Darah & HIV, Hepatitis B, CJD \\
Infeksi Saluran Cerna & Salmonella, Shigella, Hepatitis A \\
Infeksi Luka & Streptococcus pyogenes, Staphylococcus \\
& aureus \\
Infeksi Septikemia & Typhoid, Paratyphoid, Meningococcus \\
Infeksi Saluran Nafas & Tuberculosis \\
\hline
\end{tabular}

Advisory committee on dangerous pathogens (ACDP) mengkategorikan agen infeksius menjadi 4 kelompok bahaya (hazard group) berdasarkan tingkat virulensi agen infeksi, tingkat penyebaran dan kemampuannya untuk menjadi epidemik, tingkat pencegahan agen infeksi dan tingkat kesembuhan post infeksi. Berdasarkan kelompok tersebut, pekerja di ruang autopsi lebih beresiko untuk terkena infeksi dari hazard group 3 dan 4, sedangkan hazard group 2 lebih sering terjadi pada praktek klinis dan akhir-akhir ini kejadian semakin meningkat pada pekerja di ruang autopsi. ${ }^{13}$

Hazard group 1 adalah kelompok yang tidak menimbulkan penyakit pada manusia. Hazard group 2 merupakan agen infeksius dimana organisme yang resisten terhadap antibiotik seperti: Methicillin Resistent Staphylococcus aureus (MRSA), Vancomycin-resistent Enterococci (VRE), Salmonella spp dan 
bakterik enterik patogen lainnya serta Leptospira spp. Rute transmisi agen biologi ini melalui tangan ke mulut "hand to mouth". Prosedur higiene yang baik termasuk cara mencuci tangan yang benar dapat mengurangi angka transmisi dari kelompok ini. Meskipun inokulasi dari Staphylococcus, Meningococcus dan Streptococcus masih mungkin terjadi tetapi dengan standar pencegahan universal modern hal ini bisa diminimalisir. ${ }^{13}$

Hazard group 3 merupakan infeksi dari kelompok ini disebabkan oleh agen biologi yang bisa menimbulkan penyakit serius pada manusia dan memiliki bahaya serius pada pekerja di ruang autopsi. Meskipun agen biologi memiliki resiko besar untuk menyebar luas, pengobatan dan pencegahan yang efektif telah tersedia. Agen biologi yang sering menimbulkan infeksi pada kelompok ini adalah tuberkulosis, HIV, Hepatitis B dan Hepatitis C. ${ }^{13}$

Hazard group 4 merupakan infeksi dari kelompok ini disebabkan oleh agen biologi yang bisa menimbulkan penyakit serius pada manusia dan memiliki bahaya serius pada pekerja diruang autopsi. Agen biologi ini memiliki resiko besar untuk menyebar luas dan pengobatan serta pencegahan yang efektif tidak tersedia. Agen biologi yang sering menimbulkan infeksi pada kelompok ini adalah Viral Haemorraghic Fever (VHF), Marburg, Ebola, Lassa fever, Congo-crimea haemorraghic fever. 13

\section{Kewaspadaan Universal di Ruang Autopsi}

Salah satu cara untuk mencegah terjadinya infeksi saat autopsi adalah dengan menggunakan alat pelindung diri (APD) saat melakukan autopsi. ${ }^{13}$ The Co-op Funeral Service Managers Association merekomendasikan standar tertinggi kebersihan personal untuk menggunakan pakaian pelindung yaitu berupa: 1. sarung tangan dari karet yang resisten terhadap air dan bahan kimia, 2. sepatu boots dari karet yang anti slip, 3. baju operasi /gaun lengan panjang yang tahan air dengan ukuran yang cukup panjang hingga di atas boots, 4. apron dari bahan plastik, 5 . masker wajah, 6. kaca mata untuk melindungi mata dari percikan cairan tubuh, dan 7. penutup kepala. Pakaian perlindung untuk personal sesuai dengan standar dapat dilihat pada gambar 1.

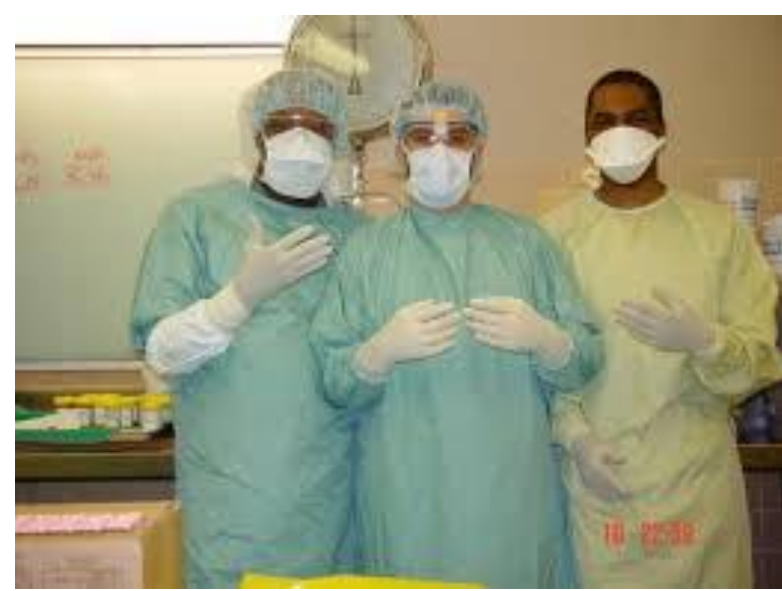

Gambar 1. Peralatan Perlindungan Diri

Selain menggunakan alat pelindung diri, tindakan aseptik seperti mencuci tangan dengan benar sebelum dan sesudah autopsi juga dapat menurunkan resiko infeksi saat autopsi. $^{13,14}$ Selain itu tidak menggunakan pakaian autopsi diluar kamar autopsi, teknik autopsi yang benar seperti cara menggunakan scalpel yang benar juga dapat menghindarkan dari 
perlukaan yang dapat menjadi tempat masuk agen-agen infeksi. Perlu diberlakukan kewaspadaan universal (universal precaution) dan standar OSHA untuk mengurangi resiko dan meningkatkan kewaspadaan terhadap infeksi saat autopsi. ${ }^{13}$

Sesuai konsep kewaspadaan universal, seluruh darah beserta komponennya dan seluruh cairan tubuh harus diperlakukan sama sebagai darah yang terinfeksi HIV, HBV dan patogen yang penularannya lewat darah. Cairan tubuh yang dimaksud di atas adalah semen, sekresi vagina, cairan serebrospinal, cairan sinovial, cairan pleura, cairan perikardial, cairan peritoneal, cairan amnion, dan air ludah. ${ }^{14}$

Jika terjadi paparan dengan mayat yang beresiko menularkan infeksi yang berbahaya segera konsul ke dokter. Beberapa infeksi sulit diidentifikasi segera sehingga tindakan pencegahan mesti dilakukan untuk mengurangi resiko. Pada infeksi HIV contohnya, konsul pada dokter agar bisa mengevaluasi apakah antiretroviral dibutuhkan atau tidak. ${ }^{15}$

\section{Disinfeksi di Ruang Autopsi}

Disinfeksi berarti proses penghancuran agen biologis hingga ke level tidak membahayakan dan telah menghilangkan resiko penularan. Cairan disinfektan tidak membunuh semua agen biologis dan biasanya tidak merusak spora bakteri. Pembunuhan semua agen biologis disebut dengan sterilisasi. Namun, disinfeksi sering dianggap lebih tepat jika kondisi steril tidak diperlukan ataupun jika sterilisasi menyebabkan kerusakan pada peralatan atau permukaan benda, serta jika benda seperti lantai tidak dapat disterilkan. ${ }^{16}$ Faktor yang dipertimbangkan dalam pemilihan disinfektan adalah memenuhi persyaratan control of substances hazardous to health $(\mathrm{COSHH})$, misalnya mempunyai resiko yang rendah untuk kesehatan pekerja di ruang autopsi. Sesuai dengan peralatan di ruang autopsi dan aktifitas antimikroba. ${ }^{6}$

Tabel 2. Aktifitas Beberapa Kelompok Disinfektan. ${ }^{6}$

\begin{tabular}{lccc}
\hline \multicolumn{1}{c}{ Golongan Disinfektan } & Bakteri Vegetative & Mycobacteria & Spora Bakteri \\
\hline Phenolics & + & + & - \\
Hypochlorites & + & + & + \\
Aldehydes & + & + & + \\
Alcohols & + & + & - \\
\hline Keterangan : & & & \\
$-\quad$ tidak aktif & & & \\
$+\quad$ aktif & &
\end{tabular}


Tabel 3. Disinfektan yang Digunakan di Ruang Autopsi dan Efektifitasnya ${ }^{17}$

\begin{tabular}{lcccl}
\hline \multicolumn{1}{c}{ Disinfektan } & HIV & HBV,C,D & TB & \multicolumn{1}{c}{ Keterangan } \\
\hline $\begin{array}{l}\text { 0,5 Sodium } \\
\text { Hypochlorite Solution }\end{array}$ & + & + & - & $\begin{array}{l}\text { Inaktif untuk bahan organik digunakan } \\
\text { untuk permukaan non logam }\end{array}$ \\
$\begin{array}{l}1-2 \% \text { Glutaraldehyde } \\
10 \% \text { Formaline }\end{array}$ & ++ & ++ & + & Ideal untuk permukaan logam \\
$1-2 \%$ Soluble Phenol & - & - & - & Sifat iritasi tinggi, karsinogenik \\
Derivates & & & ++ & Tidak korosif terhadap logam dan aktif \\
\end{tabular}

Keterangan :

- : tidak aktif

+ : aktif

Penanganan ruangan autopsi menurut Department of Health, Food and Environment Hygiene Department adalah sebagai berikut: seluruh permukaan harus dikontaminasi dengan "1 di dalam 49 larutan natrium hipoklorit" (campurkan 1 bagian natrium hipoklorit dengan 49 bagian air), diamkan selama 15-30 menit dan bilas dengan air. Permukaan yang berasal dari logam dibersihkan dengan alkohol $70 \%$. Permukaan yang terkontaminasi dengan darah atau cairan tubuh lain dibersihkan dengan "1 dalam 4 larurtan natrium hipoklorit" (campurkan 1 bagian natrium hipoklorit 5,25\% dengan 4 bagian air), diamkan selama 10 menit kemudian bilas dengan air. ${ }^{18}$

Berikutnya sampah medis harus ditangani dengan baik dan alat-alat autopsi harus di autoklaf atau didekontaminasi dengan larutan disinfektan. Ruang autopsi harus dijaga selalu bersih dan ventilasinya baik serta pencahayaan yang adekuat. Begitu juga dengan tempat penyimpanan jenazah harus mudah dibersihkan dan dirawat. Merokok, minum dan makan di ruang autopsi tidak diperbolehkan. Kemudian linen harus ditangani sesuai standar. Linen yang terkontaminasi darah atau cairan tubuh lain di cuci dengan mesin cuci dengan air panas $\left(>70{ }^{\circ} \mathrm{C}\right)$ dan diberi larutan 1 bagian $5,25 \%$ natrium hipoklorit dengan 49 bagian air selama 30 menit sebelum dicuci. Jangan lupa sarung tangan, personal protective equipment lainnya, alkohol, hand rub dan disinfektan seperti natrium hipoklorit selalu tersedia. Setelah penggunaan sarung tangan dan pakaian penlidung harus diletakkan di dalam kantong plastik. ${ }^{18}$

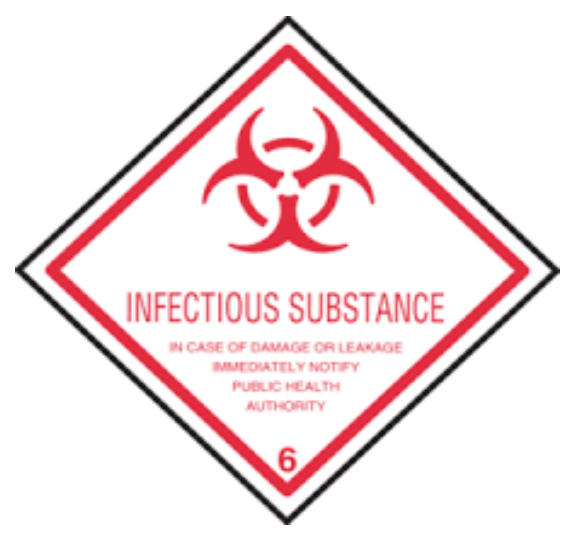

Gambar 2. Logo Biohazard

Penanganan Sampah Medis

Berdasarkan WHO, pelabelan terhadap setiap sampah infeksius termasuk limbah medis harus dibuat 
dengan jelas dan diberi logo seperti yang terlihat pada gambar 2. ${ }^{19}$ Pencegahan penularan infeksi dari limbah medis dapat dilakukan dengan cara yaitu: letakkan limbah medis didalam kotak atau kantong yang masing-masing berwarna sebagai kode. Letakkan benda tajam pada kotak yang tahan bocor dan tahan tusukan. Ganti kotak jika sudah penuh $3 / 4$ bagian. Letakkan rembesan darah, tetesan darah, gumpalan darah dan bahan limbah ke kantong plastik tahan bocor atau kotak kedap air. Tutup dan segel kotak dan kantong untuk mencegah keluarnya isi kotak selama dipindahkan, di bawa atau disimpan. Letakkkan kotak limbah medis pada kantong atau kotak tambahan jika terjadi kontaminasi dari luar atau berpotensi bocor. Hindari beban terlalu banyak atau penanganan yang kasar untuk

\section{DAFTAR RUJUKAN}

1. Hostiuc S, Curca GC, Ceausu M, Rusu MC, Niculescu E, Dermengiu D. Infectious risks in autopsy practice. Romanian J Legal Med 2011;(19):183-8.

2. Komisi Penangggulangan AIDS. Tata cara pemulasaran jenazah orang dengan HIV dan AIDS. Jawa Tengah. 2012.

3. Aida FN. Uji diagnostik deteksi antibodi HIV $1 / 2$ pada darah jenazah menggunakan alat uji cepat (Rapid Test). 2011

4. Charles V, Wetli. Autopsy safety. Center of Forensic Sciences, Happauge and Departement of Pathology, State University. New York. Laboratory Medicine 2001;32(8).

5. OSHA Compliance Guidelines for Funeral Home. Atlanta; Georgia Institute of technology. Available from mencegah robeknya kotak atau kantong. Ikuti segala aturan tentang limbah medis.

\section{SIMPULAN}

Resiko penularan infeksi di ruang autopsi sangatlah tinggi karena meningkatnya kematian akibat penyakit infeksi terutama di negara berkembang. Tindakan untuk mencegah terjadinya penularan infeksi berupa penerapan kewaspadaan universal meliputi penggunaan alat pelindung diri yang tepat, perilaku dan tindakan mencegah infeksi serta disinfeksi dan penanganan sampah medis. Pemilihan disinfekatan yang digunakan harus mempertimbangkan bahaya larutan disinfektan, spektrum mikribiosidal, zat-zat yang menonaktifkan atau faktor lain yaitu kontak, durasi serta konsentrasi. https://www.funeralcourse.com/wpcontent/uploads/southcarolina/SCOSHA-Compliance-Guidance-FuneralHomes-6hr.pdf

6. Creely KS. Infection risks and embalming. Research Report. Institutes Occupational Medicine 2004.

7. Sotgiu G, Arbore AS, Cojocariu V, Piana A, Ferrara G, Cirillo DM, Matteelli A. High risk of tuberculosis in health care workers in Romania. Int $\mathrm{J}$ Tuberc Lung Dis 2008;122:600-11.

8. Lundgren R, Norrman E, Asberg I. Tuberculosis infection transmitted at autopsy. Tubercle 1987;68(2):147-500.

9. CDC. Biosafety in Microbiological and Biomedical Laboratories. $5^{\text {th }}$ ed. U.S. Departement of Health and Human Service Public Health Service. Centers for Disease Control and Prevention. 
National Institutes of Health, HHS Publication 2009: 21-1112.

10. Maruna H, Westphal G. Epidemiology and risk calculation of hepatitis $B$ as an occupational disease in the Austrian health service. Int Arch Occup Environ Health 1986;57:259-65.

11. Komiya $\mathrm{Y}$, Katayama K, Yugi H, Mizui $M$, Matsukura $H$, Tomoguri. Minimum infectious dose of hepatitis $B$ virus in chimpanse and difference in the dynamics of viremia between genotype A and genotype C. Transfusion 2008;48: 286-94.

12. Do ANMD, Ciesielski CAMD, Metler RPJD, Hammett TAMPH, Li JDPE, Fleming PLP. Occupational acquired Human Immunodeficiency Virus (HIV) Infection: National Case surveillance data During 20 years of the HIV Epidemic in the United States. Infect Control Hospital Epidemiol 2003;24:8696.

13. The Royal College of Pathologist. Guidelines on Autopsy Practice. London 2002.

14. Jeffrey NS. Universal precaution and high risk autopsies. 2012.

15. Mortuary Unit. Standar Operating Procedures District of Columbia. Office
16. of the Chief Medical Examiner (OCME) Policy 1910. Massachusetts Avenue, SE. Washington 2003

17. Richmond. Health and Safety Executive. Safe working and the prevention of infection in mortuary and post mortem room. London, Royal Institite of Public Health 2001.

18. Shaha KK, Patra AP, Das S, Sukumar S, Mohanty MK. Awareness of risks, hazard and prevention in autopsy practice: a review. J Evolut Med Dent Sci 2013;2(22):4030-41.

19. Departemen of Health. Food and Environment Hygiene Departement. Precaution for handling and disposal of dead bodies. General Recommendations for All Related Person 2014.

20. World Health Organization. Gudance on regulation for the transport of infectious substances. Available from: http://www. who.int/ihr/publications/who_hse_ihr_ 2015.2/en/.

21. US Army Center for Health promotion and prevention medicine. Guidelines for protecting mortuary affairs personnel from potentially infectious materials. Maryland: Aberdeen Proving; 2001. 